\title{
ESTIMATES OF CHANGES IN COUNTY-LEVEL HOUSING PRICES IN THE UNITED STATES UNDER SCENARIOS OF FUTURE CLIMATE CHANGE
}

\author{
FRANCES SUSSMAN ${ }^{*} \|$, BANSARI SAHA ${ }^{\dagger}$, BRITTA G. BIERWAGEN ${ }^{\star}$, \\ CHRISTOPHER P. WEAVER ${ }^{\star}$, WILL COOPER ${ }^{\S}$, PHILIP E. MOREFIELD \\ and JOHN V. THOMAS \\ *ICF International, Environmental and Social Sustainability Division \\ 1725 Eye Street, NW, Washington DC 20006, USA \\ $\dagger$ ICF International, Environmental and Social Sustainability Division \\ 100 Cambridgepark Drive, Cambridge, MA 02140, USA \\ ${ }^{+}$US Environmental Protection Agency, Office of Research and Development \\ National Center for Environmental Assessment \\ 1200 Pennsylvania Avenue, NW, MC 8601-P, Washington DC 20460, USA \\ ${ }^{\S}$ ICF International, Environmental and Social Sustainability Division \\ 9300 Lee Highway, Fairfax, VA 22031, USA \\ "US Environmental Protection Agency, Office of Sustainable Communities \\ Community Assistance and Research Division \\ 1200 Pennsylvania Avenue, NW, MC 1807-T, Washington DC 20460, USA \\ "FSussman@rcn.com
}

Published 20 October 2014

\begin{abstract}
Climate in a given location influences people's housing decisions, and changes in climate may affect these decisions in ways that alter our understanding of desirable locations. This study examines the potential sensitivity of future housing prices in the United States to changes in temperature, precipitation, and humidity by developing a hedonic regression model of the relationship between climate variables and housing prices and exploring implications of different climate futures for the amenity value of climate in these prices. The model shows a significant relationship between housing prices in urban areas and certain climate variables. The study then examines the sensitivity of the amenity value of climate to future climate scenarios. Results suggest that, nationally, climate change represents a disamenity, particularly in centralto-southeastern states. However, detailed housing prices vary spatially and among scenarios. Seasonal variation in temperature, including the relative magnitudes of the change in January and July temperatures, is a key determinant of housing price change, contributing to variation across both climate scenarios and geographic location.
\end{abstract}

Keywords: Amenity value; climate change; quality of life; hedonic housing model; downscaled climate data.

$\|_{\text {Corresponding author. }}$ 


\section{Introduction}

Climate change will result in a variety of physical effects, including changes in temperature, precipitation, and extreme events such as flooding and hurricanes (IPCC, 2007). Climate-related changes have been observed in the United States, with likely impacts on human health, water supply, and other aspects of human and natural systems (Karl et al., 2009; Melillo et al., 2014). Efforts to quantify impacts have focused on a few sectors and on estimating metrics such as increased mortality or energy expenditures. Few studies focus on the amenity value of climate.

Local climate contributes to many aspects of quality of life (Sussman et al., 2008), including physical comfort, health, and recreational opportunities. Like other location amenities, such as good schools or short commutes, climate may influence where households choose to live and work. Because climate is valued, households and workers are willing to pay more for housing - accept lower wages — to live in areas with more desirable climates.

The hedonic valuation model is a common economic method for examining how much households are willing to pay for desirable climates. Studies applying the hedonic approach to housing markets find that climate can be a significant factor in housing prices (Clark and Cosgrove, 1990; Gyourko and Tracy, 1991; Kahn, 2009; Albouy et al., 2013). A few studies have taken the next step of quantifying the impact of changes in climate on these markets (Mendelsohn, 2001; Kahn, 2009; Albouy et al., 2013).

This study explores how future climate might affect the direction and relative magnitude of amenity or disamenity effects on housing prices, nationally and regionally in the US. The cross-sectional, national hedonic housing-value model developed for this study uses unit-level data on owner-occupied houses and historical data on temperature, precipitation, and relative humidity. This study then applies the estimated relationship between climate variables and housing values to four scenarios of future climate, providing estimated marginal changes in future housing values at the county, state, and national levels.

This study builds on and expands the existing literature in important ways. First, the housing dataset includes individual household-level data in mostly urban counties. The data are a representative sample of counties that contain about $68 \%$ of owner-occupied houses and the major housing markets. The dataset covers over 1.3 million households in large and small cities, excluding only rural, sparsely populated counties. The use of household-level data (rather than county averages) as has also been the case in several recent studies (for example, Sinha and Cropper, 2013; Albouy et al., 2013) enables modeling direct relationships between climate and household preferences as reflected in house price. Covering a broad geographic area provides variation in climate to estimate the hedonic relationship for a range of conditions. Moreover, the geographic scope ensures that the impacts estimated are representative of the entire US, particularly the major housing markets, and not an artifact of an individual county or location. 
Second, the study uses both historical climate data and multiple scenarios of future climate. Specifically, multiple General Circulation Models (GCMs), dynamically downscaled with multiple Regional Climate Models (RCMs), provide four distinct scenarios of future climate, thereby allowing an exploration of the effects of climate model-based uncertainty on the results. This approach allows an examination of the sensitivity of the amenity value of climate across a range of future climates, revealing additional insights into the interplay between the important climatic drivers of shifts in housing prices. In addition, the use of RCM downscaling combined with surface observation data provides a new level of spatial coverage and detail, making it possible to assess the effects of climate change at a more local level across the United States. Finally, the analysis uses humidity-adjusted temperature (apparent temperature or heat index) to explore the combined effects of humidity and temperature to more fully account for important "mugginess" effects on amenity values.

\section{Hedonic Markets, Climate, and Amenity Values}

People's location decisions and housing prices in different locations reflect many preferences, including a variety of climates. If warmer winter temperature is perceived as a climate amenity, individuals will bid up prices of houses in areas with warmer winters above houses in other locations, all else being equal. Both housing and wage markets should reflect such effects; individuals should pay more for houses, and accept lower wages, in more desirable areas.

This study is a proof-of-concept exercise to identify how the amenity effects of climate contribute to the desirability of living in different locations in the United States, and to explore how different climate projections affect the geographic distribution of desirable and undesirable changes in climate, as well as the overall change nationally. This study illustrates the extent to which housing prices reflect the desirability of certain climates, or the amenity value. Consequently, we focus on housing prices as a proxy for the overall market decision. This approach, focusing on housing market decisions and ignoring labor markets, is consistent with a variety of hedonic housing market research.

Hedonic theory assumes that individuals view heterogeneous goods as bundles of attributes (Rosen, 1979; Freeman, 1999). In the case of houses, these attributes may include structural characteristics (e.g., number of bedrooms), neighborhood characteristics (e.g., school quality), location (e.g., distance from recreational opportunities), environmental attributes (e.g., ambient air quality), and climate attributes (e.g., average temperature). Different houses embody different combinations of attributes, and the price paid for a house is a composite of the prices of individual attributes. ${ }^{1}$ The hedonic approach estimates the implicit value attached to each attribute by comparing

\footnotetext{
1 "Housing price" and "reported housing value" (a proxy for market price) are used interchangeably (see Harrison and Rubinfeld, 1978).
} 
differences across the housing market in observed market prices and in the quantities of various attributes associated with each house.

Researchers have long recognized climate as an important factor in the relationship among location amenities, housing values, and wages. A number of housing market and wage/earning studies in the US include temperature variables, such as annual average temperature, January and July temperatures, heating and cooling degree days, and precipitation variables, such as annual or seasonal rainfall or snowfall (Hoch and Drake, 1974; Cropper and Arriaga-Salinas, 1980; Cropper, 1981; Roback, 1982; Clark and Cosgrove, 1990, 1991; Gyourko and Tracy, 1991). More recently, studies by Koirala and Bohara (2014), Albouy et al. (2013), and Sinha and Cropper (2013) have used micro-level housing data similar to this study and analyzed the amenity effects of climate. Collectively, these studies provide evidence for a statistically significant role of climate in determining housing prices and wages, although studies differ in the magnitude, and sometimes direction of the effect.

Overall, the literature suggests a strong relationship between climate and housing and labor markets, and conforms to expectations that people prefer warmer average weather, higher winter temperatures, lower summer temperatures, and less precipitation. The evidence also suggests that the relationship is nonlinear so that extreme temperatures are less preferred. Consequently, the impact of climate change on the amenity value of climate is likely to depend on the extent to which temperatures rise, where such increases occur geographically and seasonally, the prevalence and distribution of temperature extremes, and similar factors for other important climate variables like precipitation.

\section{Estimating the Hedonic Housing Regression}

In its simplest form, the following price function empirically estimates the hedonic model:

$$
P(H)=\alpha_{0}+\sum \beta_{k} S_{k}+\sum \gamma_{j} N_{j}+\sum \theta_{i} E_{i}+\varepsilon,
$$

where $P(H)$ is the natural log of housing price (or house value as proxy), $S_{k}$ is a vector of structural housing characteristics (e.g., number of rooms); $N_{j}$ is a vector of neighborhood and household characteristics (e.g., county median household income); and $E_{i}$ is a vector of climate and other environmental attributes (e.g., temperature, air quality indices). $\alpha_{0}$ is the estimated constant term, $\beta_{k}, \gamma_{j}$, and $\theta_{I}$ are the estimated regression coefficients corresponding to vectors of attributes, and $\varepsilon$ is the regression error term. The collection of variables in the hedonic model describes the behavior of the characteristics; even if each variable coefficient is small, the aggregate contribution is meaningful. We selected suitable variables to describe housing and neighborhood characteristics and tested combinations of climate variables that reflect observed relationships with housing prices. 
Estimating the hedonic value equation requires historical data on housing prices, housing and location characteristics, and specific climate attributes. Although the unit of observation is an individual household, neighborhood and climate attributes do not vary at the unit level but are constant in a given county. This is consistent with other hedonic housing studies of national-level impacts.

The housing market equation implicitly estimates the amount homeowners are willing to pay for a marginal change in an attribute. This interpretation requires several assumptions: homeowners are mobile and can locate anywhere in the housing market, available housing and location choices are diverse, and homeowners have complete information about the attributes of available houses and locations and possess wellunderstood preferences over those attributes. Last, the housing market must be in equilibrium; given prices and choices, homeowners do not benefit by moving. The more closely these conditions are met, the more closely implicit prices in the housing market will align with the amount homeowners are willing to pay for these attributes (Sussman et al., 2008).

\subsection{Household and county data}

The data set developed for the regression analysis is cross-sectional and includes several types of data on housing and county characteristics. We focused on owneroccupied houses, since renters' decisions might depend on a different set of explanatory variables. The analysis uses Census Bureau's 2000 micro-level data (from the Public Use Microdata Sample (PUMS)) for individual houses (as reported by survey respondents) for attributes of the house and household, including value (Table 1). We subdivided the data into small- and large-city samples. County-level summary data for the year 2000 describe location and county characteristics.

Additional data on county attributes, such as crime rates, pollution levels, and recreation opportunities (e.g., accessibility to ski resorts and beaches), are derived from publicly available data from the Federal Bureau of Investigation, US Environmental Protection Agency, the Economic Research Service at USDA, and other sources (Table 1). Regression results yielded different coefficients in the two samples for climate and many other variables. To combine the samples the analysis incorporates dummy variables to capture operational differences of those variables. ${ }^{2}$ The analysis did not identify local or regional housing markets, but instead treated the large and small city datasets as though each represented a national housing market. This assumption reflects the long timeframe of the analysis (decades), during which time individuals have more flexibility in location choices than in the short term.

\footnotetext{
${ }^{2}$ The coefficient estimate for any given variable reflects the impact of that variable on small city housing prices (i.e., the base group, with the large city dummy $=0$ ). The sum of the base group coefficient and the corresponding interaction term (i.e., with the large city dummy $=1$ ) gives the impact of the variable on large city housing prices.
} 


\section{F. Sussman et al.}

Table 1. Detailed summary statistics for all non-climate variables used in the econometric analyses. Climate variable details are in Table 2.

Variable $\quad$ Mean $\begin{aligned} & \text { Standard Minimum Maximum } \\ & \text { deviation }\end{aligned}$

\begin{tabular}{|c|c|c|c|c|}
\hline \multicolumn{5}{|l|}{ Descriptive statistics $(N=1,366,089)$} \\
\hline Actual House Value $(1999 \$)$ & 167,497 & 121,906 & 5000 & 875,000 \\
\hline Number of Rooms & 6.02 & 1.34 & 1 & 8 \\
\hline Number of Bedrooms & 2.95 & 0.73 & 0 & 4 \\
\hline Age of Household (Years) & 52.3 & 15.8 & 15 & 93 \\
\hline Age of Household Squared & 2989.7 & 1762.2 & 225 & 8649 \\
\hline Sex Dummy $($ Male $=1$; Otherwise $=0$ ) & 0.71 & 0.45 & 0 & 1 \\
\hline Race Dummy (Nonwhite $=1$; Otherwise $=0$ ) & 0.18 & 0.38 & 0 & 1 \\
\hline Marriage Dummy $($ Married $=1$; Otherwise $=0$ ) & 0.66 & 0.47 & 0 & 1 \\
\hline $\begin{array}{l}\text { High School Graduate Dummy (Graduate }=1 \\
\quad \text { Otherwise }=0 \text { ) }\end{array}$ & 0.86 & 0.35 & 0 & 1 \\
\hline $\begin{array}{l}\text { County Unemployment Rate (Expressed as } \\
\text { Proportion) }\end{array}$ & 0.06 & 0.02 & 0.02 & 0.14 \\
\hline $\begin{array}{l}\text { Proportion of County Population that is Working } \\
\text { Age }\end{array}$ & 0.65 & 0.03 & 0.51 & 0.76 \\
\hline $\begin{array}{l}\text { Proportion of County Population that is } 65 \text { years } \\
\text { or older }\end{array}$ & 0.12 & 0.04 & 0.04 & 0.35 \\
\hline County Median Household Income (1999\$) & 46,625 & 10,446 & 24,863 & 82,929 \\
\hline Green Book Ozone 8 Nonattainment & 0.71 & 0.45 & 0 & 1 \\
\hline Green Book PM 2.5 Nonattainment & 0.39 & 0.49 & 0 & 1 \\
\hline $\begin{array}{l}\text { Pollution Composite Dummy (Ozone } 8 \text { Non- } \\
\text { attainment for Large Cites, PM } 2.5 \text { Non- } \\
\text { attainment for Small Cities) }\end{array}$ & 0.64 & 0.48 & 0 & 1 \\
\hline $\begin{array}{l}\text { Summer Recreation Dummy } \\
\qquad(5+\text { Beaches in County }=1 ; \text { Otherwise }=0)\end{array}$ & 0.32 & 0.47 & 0 & 1 \\
\hline $\begin{array}{l}\text { Winter Recreation Dummy } \\
\qquad(1+\text { Ski Areas in County }=1 \\
\text { Otherwise }=0)\end{array}$ & 0.22 & 0.42 & 0 & 1 \\
\hline $\begin{array}{l}\text { Recreation Composite Dummy (Summer Recrea- } \\
\text { tion Dummy for Large Cities, Winter for Small } \\
\text { Cities) }\end{array}$ & 0.32 & 0.47 & 0 & 1 \\
\hline ERS Typography Z-Score & 0.004 & 1.1 & -1.19 & 1.84 \\
\hline ERS Water Area Z-Score & 0.8 & 0.86 & -2.35 & 2.37 \\
\hline UCR Murders & 98.5 & 211.5 & 0 & 1006 \\
\hline UCR Robberies & 2896.9 & 6028.5 & 0 & 28,416 \\
\hline
\end{tabular}

Sources for data: Housing and personal data, and neighborhood characteristics were taken from the PUMS 5\% sample (http://www.census.gov/main/www/pums.html) and census data for 2000; pollution data for 2004-2006 from EPA's Internet Green Book (http://www.epa.gov/oar/oaqps/ greenbk/); crime data from the FBI Uniform Crime Reporting (UCR) system; ERS Z-scores taken from McGranahan (1999); data for recreation dummy based on the data of skiing (www.weather. com), national parks (www.nps.gov), and beaches (EPA's national list of beaches as of March 2004; http://water.epa.gov/type/oceb/beaches/list_index.cfm). 


\subsection{Baseline historical climate data}

The models tested reflect different interpretations of common expectations about individual preferences to climate. The models use variables representing annual, seasonal, and quadratic forms of (apparent) temperature and precipitation, as well as annual and summer relative humidity (Table 2). Choices of climate variables reflect a combination of expected relevance to amenity value and their availability in historical and simulated datasets.

The study calculates historical climate variables using data from several different sources. The variables are derived using data for roughly the decade directly proceeding the year of the PUMS data. The intent was to capture climate data that were most likely to influence housing values in the year 2000, given the influence of

Table 2. Summary statistics for baseline historic and simulated future climate.

\begin{tabular}{|c|c|c|c|c|}
\hline Variable & Mean & $\begin{array}{l}\text { Standard } \\
\text { deviation }\end{array}$ & Min & Max \\
\hline \multicolumn{5}{|l|}{ Historical Climate } \\
\hline Average Annual Temperature $\left({ }^{\circ} \mathrm{F}\right)$ & 57.38 & 9.02 & 38.97 & 77.50 \\
\hline Average Annual Temperature Squared & 3373.87 & 1086.53 & 1518.46 & 6006.52 \\
\hline Longest Streak of Days with No Precipitation & 12.54 & 10.24 & 3 & 47 \\
\hline Average Annual Precipitation (Inches) & 38.39 & 13.66 & 3.82 & 70.06 \\
\hline Proportion of Days with no Precipitation & 0.82 & 0.13 & 0.43 & 0.97 \\
\hline Average January Temperature $\left({ }^{\circ} \mathrm{F}\right)$ & 39.79 & 12.92 & 7.85 & 69.14 \\
\hline Average July Temperature $\left({ }^{\circ} \mathrm{F}\right)$ & 75.32 & 7.56 & 55.39 & 91.74 \\
\hline Average Relative Humidity, Annual (\%) & 75.81 & 10.10 & 37.45 & 86.41 \\
\hline Average Relative Humidity, Summer (\%) & 76.65 & 10.28 & 37.02 & 87.55 \\
\hline Hurricane Landfall Probability (50 years) & 3.33 & 8.84 & 0 & 44.74 \\
\hline \multicolumn{5}{|l|}{ Climate Scenario: CRCM_CCSM (CS1) } \\
\hline Average Annual Temperature $\left({ }^{\circ} \mathrm{F}\right)$ & 61.48 & 9.40 & 43.53 & 82.96 \\
\hline Average Annual Temperature Squared & 3868.34 & 1215.29 & 1895.16 & 6881.62 \\
\hline Average Annual Precipitation (Inches) & 34.82 & 14.04 & 2.03 & 62.45 \\
\hline Average January Temperature $\left({ }^{\circ} \mathrm{F}\right)$ & 43.11 & 12.40 & 15.82 & 67.07 \\
\hline Average July Temperature $\left({ }^{\circ} \mathrm{F}\right)$ & 81.46 & 9.54 & 61.54 & 99.69 \\
\hline Average Relative Humidity, Annual (\%) & 73.79 & 11.70 & 29.04 & 86.17 \\
\hline Average Relative Humidity, Summer (\%) & 69.54 & 15.23 & 20.82 & 86.76 \\
\hline \multicolumn{5}{|l|}{ Climate Scenario: CRCM_CGCM3 (CS2) } \\
\hline Average Annual Temperature $\left({ }^{\circ} \mathrm{F}\right)$ & 61.21 & 9.31 & 41.92 & 82.27 \\
\hline Average Annual Temperature Squared & 3833.51 & 1195.56 & 1757.07 & 6769.00 \\
\hline Average Annual Precipitation (Inches) & 40.27 & 13.46 & 5.54 & 67.20 \\
\hline Average January Temperature $\left({ }^{\circ} \mathrm{F}\right)$ & 42.89 & 12.14 & 12.96 & 70.53 \\
\hline Average July Temperature $\left({ }^{\circ} \mathrm{F}\right)$ & 81.02 & 8.71 & 57.87 & 97.39 \\
\hline Average Relative Humidity, Annual (\%) & 74.74 & 10.50 & 34.05 & 85.78 \\
\hline Average Relative Humidity, Summer (\%) & 70.19 & 14.82 & 24.89 & 87.59 \\
\hline
\end{tabular}


Table 2. (Continued)

\begin{tabular}{|c|c|c|c|c|}
\hline Variable & Mean & $\begin{array}{l}\text { Standard } \\
\text { deviation }\end{array}$ & Min & $\operatorname{Max}$ \\
\hline \multicolumn{5}{|l|}{ Climate Scenario: RCM3_GFDL (CS3) } \\
\hline Average Annual Temperature $\left({ }^{\circ} \mathrm{F}\right)$ & 59.92 & 9.33 & 39.31 & 80.80 \\
\hline Average Annual Temperature Squared & 3677.10 & 1176.43 & 1545.62 & 6528.52 \\
\hline Average Annual Precipitation (Inches) & 39.49 & 14.25 & 3.55 & 73.64 \\
\hline Average January Temperature $\left({ }^{\circ} \mathrm{F}\right)$ & 42.40 & 13.38 & 8.77 & 74.55 \\
\hline Average July Temperature $\left({ }^{\circ} \mathrm{F}\right)$ & 78.79 & 8.85 & 57.15 & 95.14 \\
\hline Average Relative Humidity, Annual (\%) & 73.48 & 11.18 & 31.22 & 84.70 \\
\hline Average Relative Humidity, Summer (\%) & 68.90 & 15.39 & 21.79 & 87.66 \\
\hline \multicolumn{5}{|l|}{ Climate Scenario: WRFG_CCSM (CS4) } \\
\hline Average Annual Temperature $\left({ }^{\circ} \mathrm{F}\right)$ & 60.51 & 8.99 & 42.46 & 80.33 \\
\hline Average Annual Temperature Squared & 3742.02 & 1138.48 & 1803.18 & 6453.42 \\
\hline Average Annual Precipitation (Inches) & 36.33 & 13.50 & -13.13 & 63.88 \\
\hline Average January Temperature $\left({ }^{\circ} \mathrm{F}\right)$ & 43.06 & 13.36 & 13.88 & 69.82 \\
\hline Average July Temperature $\left({ }^{\circ} \mathrm{F}\right)$ & 78.69 & 8.45 & 60.46 & 95.06 \\
\hline Average Relative Humidity, Annual (\%) & 73.72 & 11.19 & 30.35 & 85.71 \\
\hline Average Relative Humidity, Summer (\%) & 70.20 & 14.45 & 24.88 & 88.15 \\
\hline
\end{tabular}

relatively recent weather events on homeowner perceptions of climate. Table 2 provides summary statistics for the baseline climate data.

For temperature and humidity, the study uses gridded, 6-hourly, 2.5-degree NCEP/ NCAR reanalysis data for 1990 through 1999 (Kalnay et al., 1996). These data were interpolated to the centroid of each study county to construct 10-year average measures of elevation-adjusted heat index (i.e., "apparent temperature," or temperature adjusted for relative humidity), ${ }^{3}$ and relative humidity alone. The larger spatial scale of the reanalysis data may better reflect average climate over a broader domain compared to weather station data. The reanalysis data also has a resolution more similar to the future climate scenarios (Mearns et al., 2009, 2007).

Precipitation data were taken from the gridded, daily, 0.25-degree Climate Prediction Center Unified Precipitation dataset (Higgins et al., 1996). These data were interpolated to county centroids to create county averages for the period 1990-1998 (1998 being the last year of this dataset). Hurricane probability data from the U.S. Landfalling Hurricane Probability Project were also included to control for housing values affected by hurricane probabilities in hurricane-prone areas.

Figures A.1(a)-A.1(c) (see online Appendix) illustrate the variation in seasonal baseline apparent temperature and precipitation across the states. Counties in central

\footnotetext{
${ }^{3}$ We use humidity-adjusted apparent temperature (heat index) to account for the effect of humidity on human thermal comfort at higher temperatures and the implications of climate change on the distribution of effects (Willet and Sherwood, 2012). Apparent temperature is greater than observed temperature when observed temperature is above $80^{\circ} \mathrm{F}$ and relative humidity is above $40 \%$.
} 
and northern states tend to have lower January and July temperatures (Figs. A.1(a) and A.1(b), respectively), while western states tend to be drier (Fig. A.1(c)). Larger states, notably California and Texas, also display variability in both temperature and precipitation within the state.

\section{Climate Scenarios and Housing Prices}

Climate scenario data replaces historical climate data in the regression model (holding other variables constant) to estimate housing prices in the future. This results in estimates of the value of each house and a calculation of the change in house value between the scenario and historical value. For each climate scenario, the percentage change in house price is identical for all houses in a county, because (1) the dependent variable is a natural log, so that regression coefficients represent percentage changes in the dependent variable for a unit change in the independent variable; (2) climate variables are county-wide and not household specific; and (3) other variables are held constant over time. These results represent a rough estimate of the impact of climate change on housing values in urban markets.

It is a standard practice to examine multiple dimensions of modeling uncertainty, for example by incorporating different GCMs, emissions pathways, and methodologies for "downscaling" to finer spatial scales when using climate change scenarios. Different GCMs produce different results, and no one model is unambiguously more accurate, particularly at regional spatial scales (Gleckler et al., 2008).

This study uses scenarios of future climate drawn from the archives of the North American Regional Climate Change Assessment Program (NARCCAP) (Mearns et al., 2009, 2007). ${ }^{4}$ By using different combinations of climate models, the study examines two important sources of uncertainty in our climate scenarios, CS1-CS4: The GCM and the RCM used to downscale GCM output (Table 3). Two scenarios rely on the same GCM but different RCMs, one uses a second GCM downscaled by one of the

Table 3. Global and regional model combinations from the North American Regional Climate Change Assessment Program (NARCCAP) database (Mearns et al., 2009, 2007) used as Climate Scenarios (CS) in regression model.

\begin{tabular}{|c|c|c|}
\hline Scenario & Regional climate model & General circulation model \\
\hline CS1 & Canadian Regional Climate Model (CRCM) & Community Climate System Model (CCSM) \\
\hline CS2 & $\mathrm{CRCM}$ & $\begin{array}{l}\text { Third Generation Coupled Global Climate } \\
\text { Model (CGCM3) }\end{array}$ \\
\hline CS3 & Regional Climate Model version 3 (RCM3) & $\begin{array}{l}\text { Geophysical Fluid Dynamics Laboratory } \\
\text { GCM (GFDL) }\end{array}$ \\
\hline CS4 & $\begin{array}{l}\text { Weather Research and Forecasting model } \\
\text { (WRFG) }\end{array}$ & CCSM \\
\hline
\end{tabular}

${ }^{4}$ http://www.narccap.ucar.edu/. 


\section{F. Sussman et al.}

same RCMs, and a fourth uses a different GCM and RCM than the other three. The RCMs dynamically downscale output from several GCMs to a $50 \times 50 \mathrm{~km}$ grid over North America. The archive contains downscaled output for two 30-year periods (1971-2000 and 2041-2070) at a temporal resolution of $3 \mathrm{~h}$.

We derived average values for apparent temperature, precipitation, and relative humidity by month for two different 10-year periods: 1990-1999 and 2041-2050. Future climate scenarios use the difference between these periods (using percent change for precipitation) for each month applied to historical climate data. Other climate attributes (e.g., hurricane landfalls) remain constant. Applying these "change factors" to the historical climate data used to develop the regressions ensures a degree of methodological consistency between the calculated historical and potential future amenity values.

Table 2 also presents summary statistics for the four climate scenarios. Average annual, January, and July apparent temperatures (i.e., humidity-adjusted temperature, or heat index, which applies primarily in summertime) rise in all four scenarios. CS1 shows the greatest rise in apparent temperature, more than $4^{\circ} \mathrm{F}$, followed by CS2, then CS4 and CS3 at 3.0 and $2.5^{\circ} \mathrm{F}$, respectively. The spatial and seasonal patterns of apparent temperature change vary across the scenarios, as illustrated in Figs. A.2(a) and A.2(b) (see online Appendix). Consequently, the ratio of the rise in July versus January temperatures differs across scenarios, with average July apparent temperatures rising roughly twice as much as average January temperatures in CS1 and CS2, and closer to the same amount in CS3 and CS4. Since January increases tend to be an amenity and July increases (above a certain level) a disamenity, differences in seasonal temperature change should affect the change in future housing prices. The pattern of precipitation change also varies across scenarios, as indicated in Fig. A.2(c) (see online Appendix). CS1 and CS4 result in lower average precipitation (an amenity), although there are pockets regionally and in some states where precipitation increases. CS2 and CS3 generally result in increased average precipitation, although each scenario has a few exceptions in different states and regions.

\section{Relationship Between Climate and Housing Prices}

Regression results for the primary and alternate models show a strong link between climate and housing prices (Table 4). The link between climate variables and housing prices appears robust across models that represent different combinations of climaterelated explanatory variables.

The primary model has more statistically significant coefficients and greater stability in terms of magnitude and signs of coefficients of key climate variables (apparent temperature, precipitation, and relative humidity) compared with the alternate model (Table 4). Importantly, the functional forms of climate variables are consistent with previous studies, and the signs of coefficients conform to intuitions about the role of climate in preferences. Both models include large city dummies and interaction terms. 


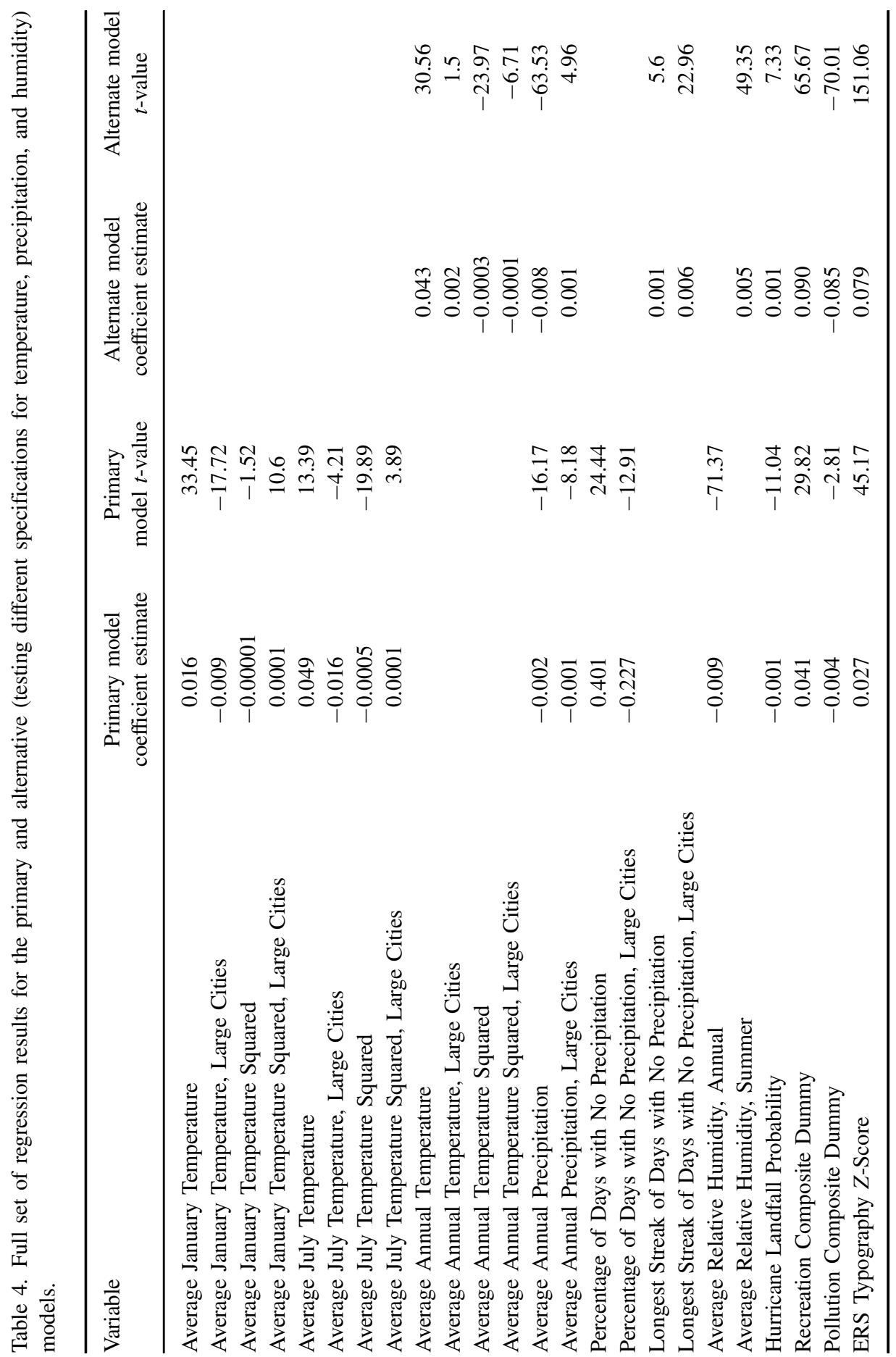




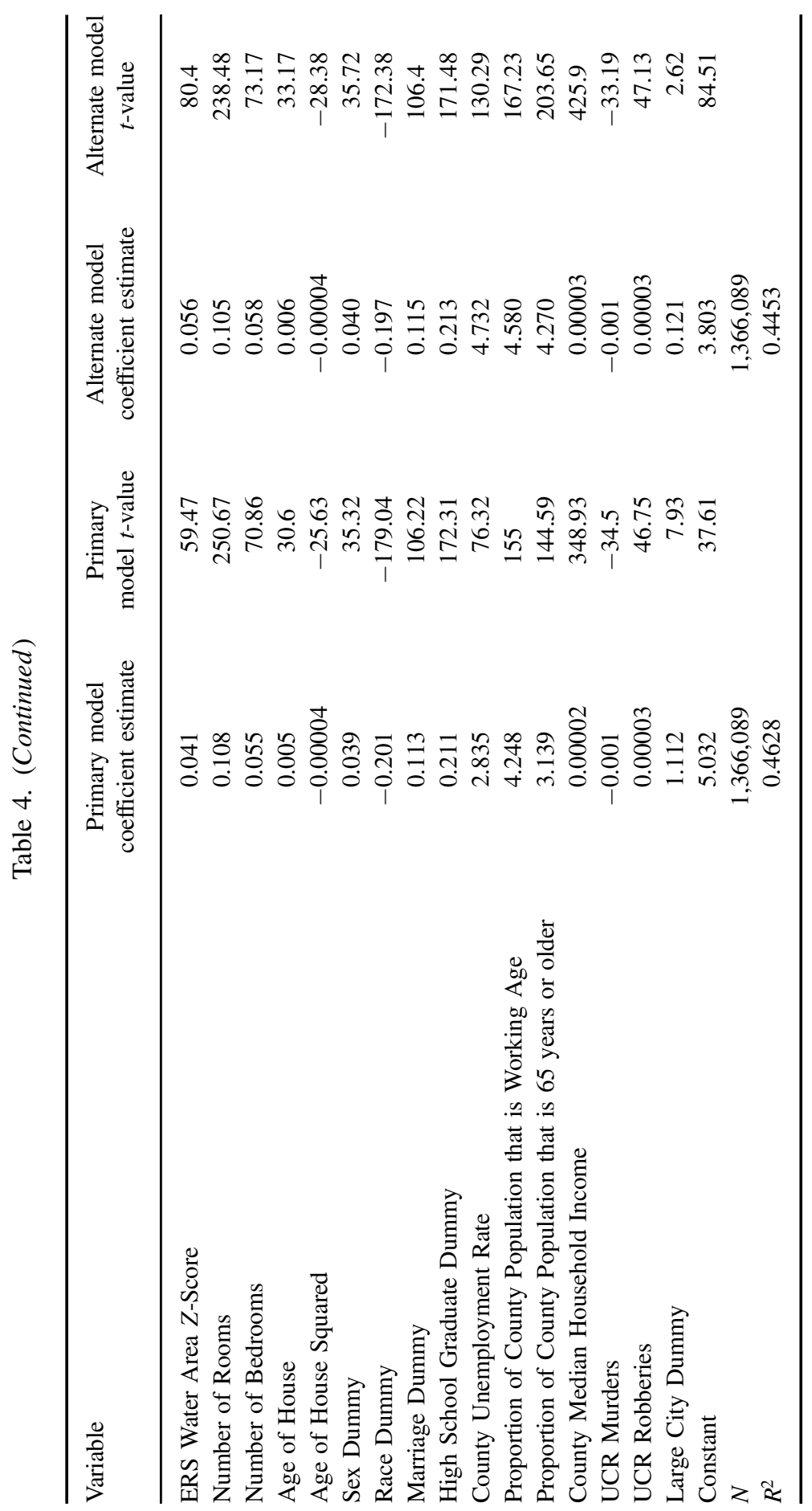




\subsection{Regression results for climate}

The primary model includes January temperature and July apparent temperature, along with a quadratic term for each to reflect the importance of extreme temperatures in housing-price preferences (Table 4). The coefficient for January temperatures is positive, matching expectation and evidence from other studies about preferences for warmer winters (Clark and Cosgrove, 1990; Mendelsohn, 2001; Rehdanz and Maddison, 2009). Although the coefficient for July apparent temperature is also positive, the quadratic term is relatively strong and negative, supporting the expectation that, above a certain degree of warmth, individuals prefer milder summers. In addition to temperature, this model includes terms for annual relative humidity, precipitation, hurricanes, and percentage of days without precipitation, all of which are disamenities. $^{5}$

The alternate model uses annual average temperature and a quadratic temperature term, and relies on the expectation that individuals prefer warmer average temperatures in general but dislike very warm temperatures. Because it uses average rather than seasonal temperatures, the alternate model is more likely than the primary model to find that climate change will be an amenity. The alternate model performed slightly worse in terms of the resulting signs of some variables (Table 4).

The combined influence of the coefficients for temperature and temperature squared illustrates the statistical contribution of temperature attributes to housing price (Fig. 1),

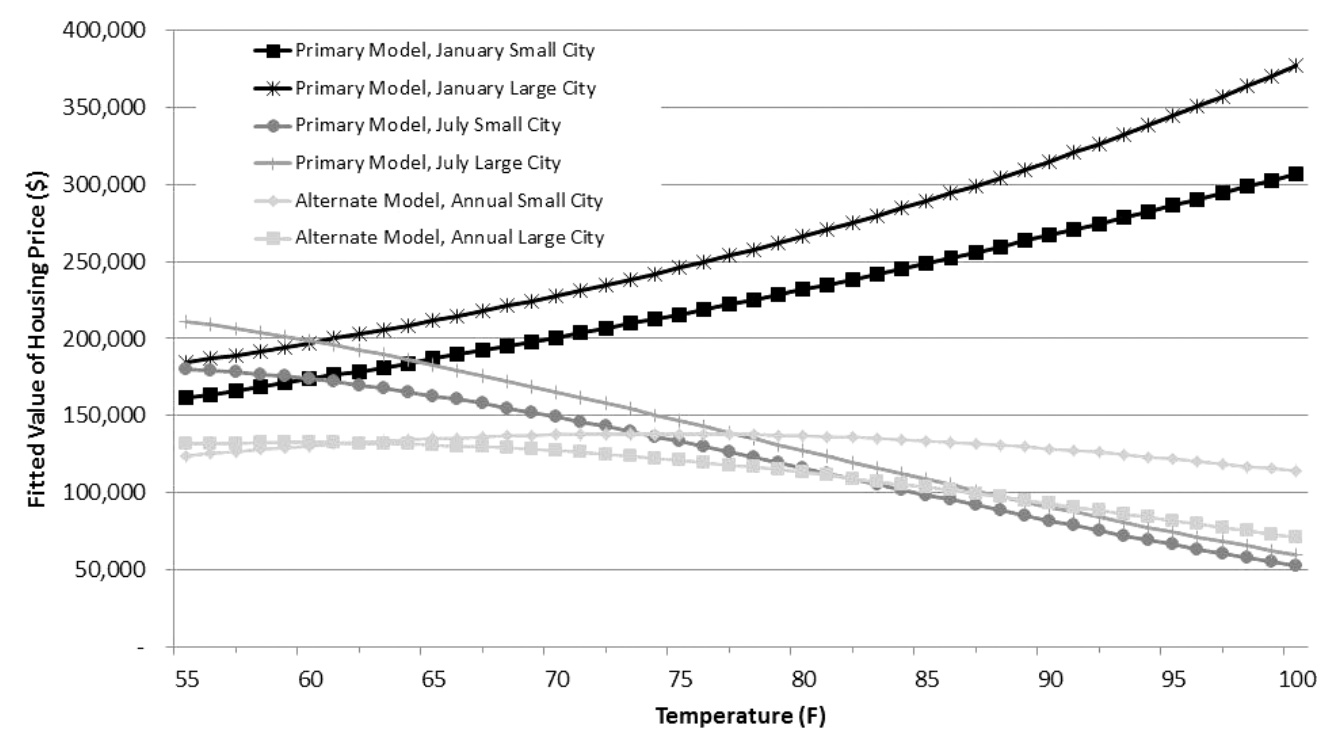

Figure 1. Implications of regression coefficients for housing prices (average annual, January, and July apparent temperatures $\left({ }^{\circ} \mathrm{F}\right)$ )

\footnotetext{
${ }^{5}$ Neither published literature nor our regression results establish reliable preferences regarding precipitation; therefore, we use a simpler configuration of variables that perform reasonably across models.
} 
evaluating all other variables at their mean values. In the primary model, for both large and small cities, rising July apparent temperature results in declining housing prices over the relevant range, reflecting a general preference for cooler summers. By contrast, across the full range of January temperatures, higher temperatures are an amenity and result in higher housing prices. This effect likely results because winters in most cities in the United States are generally colder than most people would prefer (i.e., wintertime temperatures do not reach the point at which higher temperatures might become a disamenity). Quantitative thresholds for these effects vary slightly across large and small cities and across the primary and alternate models. In the alternate model, housing prices rise with average annual temperature and then decline, suggesting that higher annual temperatures are a disamenity.

\subsection{Future housing prices}

Substituting future climate data for historical data in the primary model shows the sensitivity of housing prices to the future amenity or disamenity value of climate change across the US. Table 5 summarizes the change in simulated housing prices nationally for four climate scenarios. All scenarios produce losses in simulated housing prices for both model forms. Losses are lower under the alternate model, which uses

Table 5. Simulated changes in housing values, United States totals.

\begin{tabular}{|c|c|c|c|c|c|c|}
\hline Model & $\begin{array}{l}\text { Climate } \\
\text { scenario }\end{array}$ & $\begin{array}{c}\text { Mean change } \\
\text { in price }\end{array}$ & $\begin{array}{l}\text { Standard } \\
\text { deviation }\end{array}$ & $\begin{array}{l}\text { Median } \\
\text { change } \\
\text { in price }\end{array}$ & $\begin{array}{c}\text { Maximum } \\
\text { change } \\
\text { in price }\end{array}$ & $\begin{array}{l}\text { Minimum } \\
\text { change } \\
\text { in price }\end{array}$ \\
\hline \multicolumn{7}{|l|}{ In value terms $(\$)$} \\
\hline \multirow[t]{4}{*}{ Primary Specification } & CS1 & $(11,135)$ & 15,610 & (9692) & 37,479 & $(77,847)$ \\
\hline & $\mathrm{CS} 2$ & $(14,643)$ & 8491 & $(13,439)$ & 11,972 & $(69,925)$ \\
\hline & $\mathrm{CS} 3$ & $(5633)$ & 6537 & (4309) & 9220 & $(42,370)$ \\
\hline & CS4 & $(2640)$ & 10,655 & $(2703)$ & 41,358 & $(39,445)$ \\
\hline \multirow[t]{4}{*}{ Alternate Specification } & CS1 & (629) & 6499 & 871 & 19,448 & $(35,718)$ \\
\hline & $\mathrm{CS} 2$ & $(6221)$ & 7366 & $(4240)$ & 10,036 & $(51,118)$ \\
\hline & $\mathrm{CS} 3$ & $(5686)$ & 6404 & (3818) & 27,719 & $(39,481)$ \\
\hline & CS4 & $(1361)$ & 6882 & $(1030)$ & 24,990 & $(34,465)$ \\
\hline \multicolumn{7}{|l|}{ In percentage terms $(\%)$} \\
\hline \multirow[t]{4}{*}{ Primary Specification } & CS1 & $-10.7 \%$ & $12.0 \%$ & $-8.6 \%$ & $10.1 \%$ & $-45.1 \%$ \\
\hline & $\mathrm{CS} 2$ & $-11.8 \%$ & $6.9 \%$ & $-11.2 \%$ & $6.0 \%$ & $-33.9 \%$ \\
\hline & $\mathrm{CS} 3$ & $-5.1 \%$ & $5.7 \%$ & $-3.5 \%$ & $4.4 \%$ & $-23.4 \%$ \\
\hline & CS4 & $-3.1 \%$ & $7.1 \%$ & $-2.4 \%$ & $12.0 \%$ & $-22.5 \%$ \\
\hline \multirow[t]{4}{*}{ Alternate Specification } & $\mathrm{CS} 1$ & $-0.3 \%$ & $4.3 \%$ & $0.7 \%$ & $10.5 \%$ & $-16.3 \%$ \\
\hline & $\mathrm{CS} 2$ & $-3.9 \%$ & $4.0 \%$ & $-3.3 \%$ & $6.7 \%$ & $-17.8 \%$ \\
\hline & $\mathrm{CS} 3$ & $-4.0 \%$ & $3.7 \%$ & $-3.5 \%$ & $8.9 \%$ & $-18.4 \%$ \\
\hline & CS4 & $-0.7 \%$ & $5.1 \%$ & $-0.8 \%$ & $14.3 \%$ & $-16.2 \%$ \\
\hline
\end{tabular}


annual average temperatures. Losses in housing value nationally of between $3 \%$ and $12 \%$ (depending on climate scenario) occur with the primary model.

While climate change appears to be a disamenity on average nationally, these values do not capture the underlying variation across counties and scenarios. Using the primary model, effects on counties range from a high gain of $12 \%$ to a maximum loss of $45 \%$, across the scenarios. All climate scenarios consistently produce a large disamenity value in central to southeastern states.

Figures 2(a) and 2(b) shows the pattern of change in housing prices by county for the primary model. The pattern differs across the four climate scenarios. CS2, which has the greatest national decline in housing prices, shows consistent declines in most

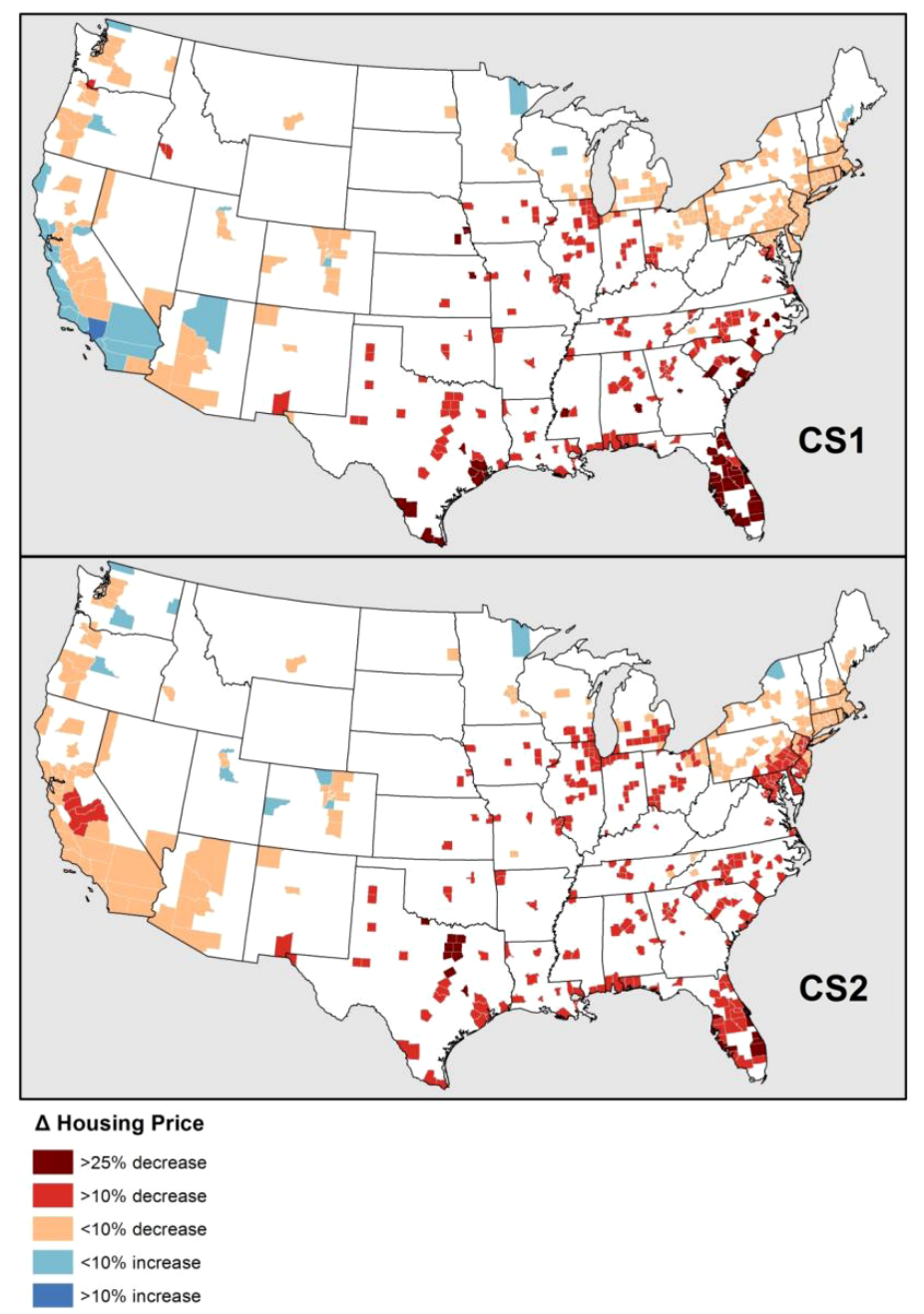

(a)

Figure 2. Percentage change in housing price (primary model) by county for all climate scenarios. (a) CS1, CS2 and (b) CS3, CS4. 


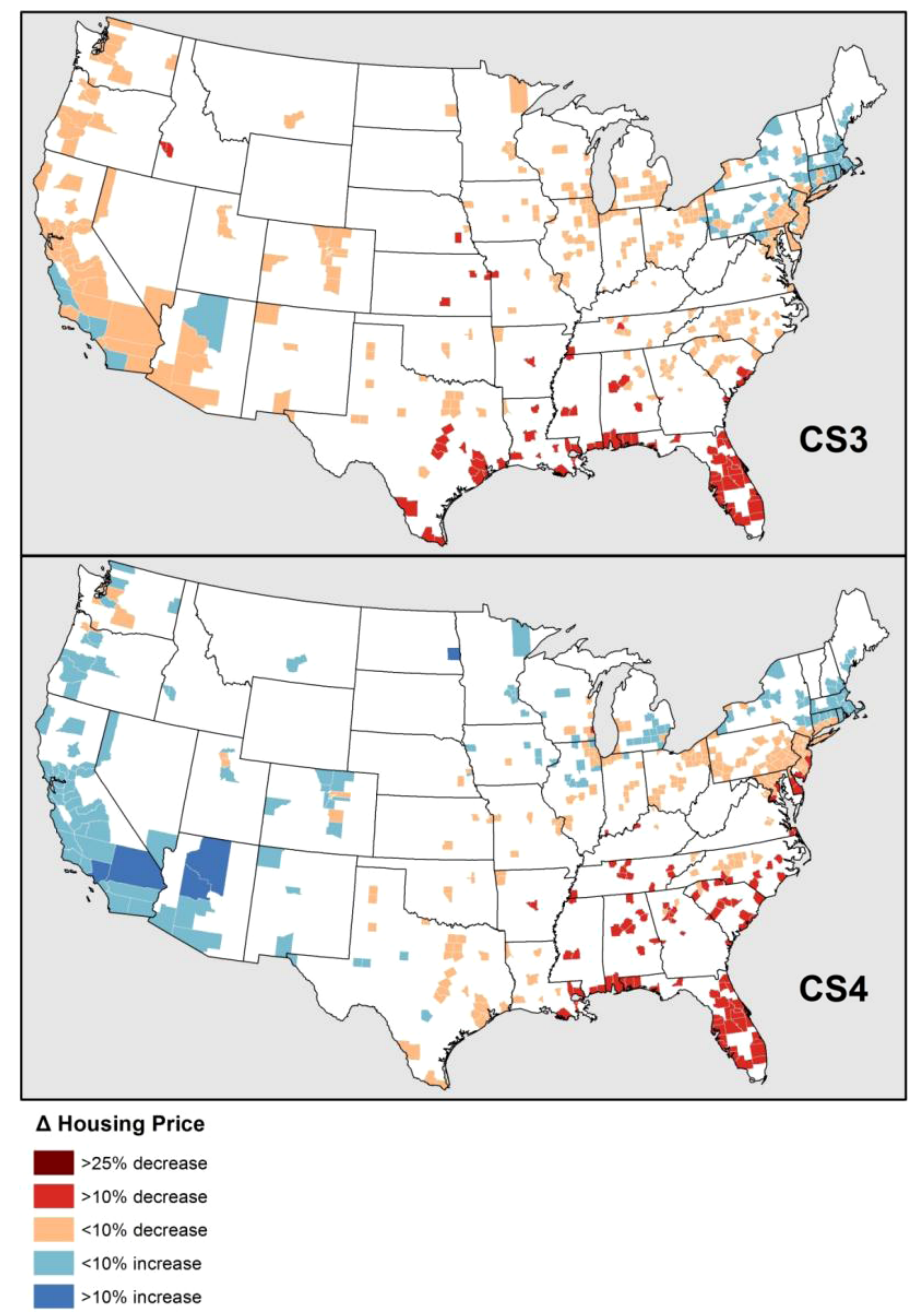

(b)

Fig. 2. (Continued)

states except Colorado, Minnesota, New York, Oregon, Utah, and Washington, with losses frequently exceeding $10 \%$ east of the 100th meridian. CS1, which also shows a large national disamenity, has positive changes of less than $10 \%$ in a single county each in Arizona, Colorado, Maine, Minnesota, Oregon, Utah, Washington, and Wisconsin, and most of the counties in California show positive values. CS3 shows small increases in the Northeast, Arizona, and California. CS4, which shows the smallest national decline, has the greatest number - almost half - of states showing an amenity value of climate, with the largest increases in Arizona and California. Many of the states that show an amenity value of climate are among the colder or less humid states. 

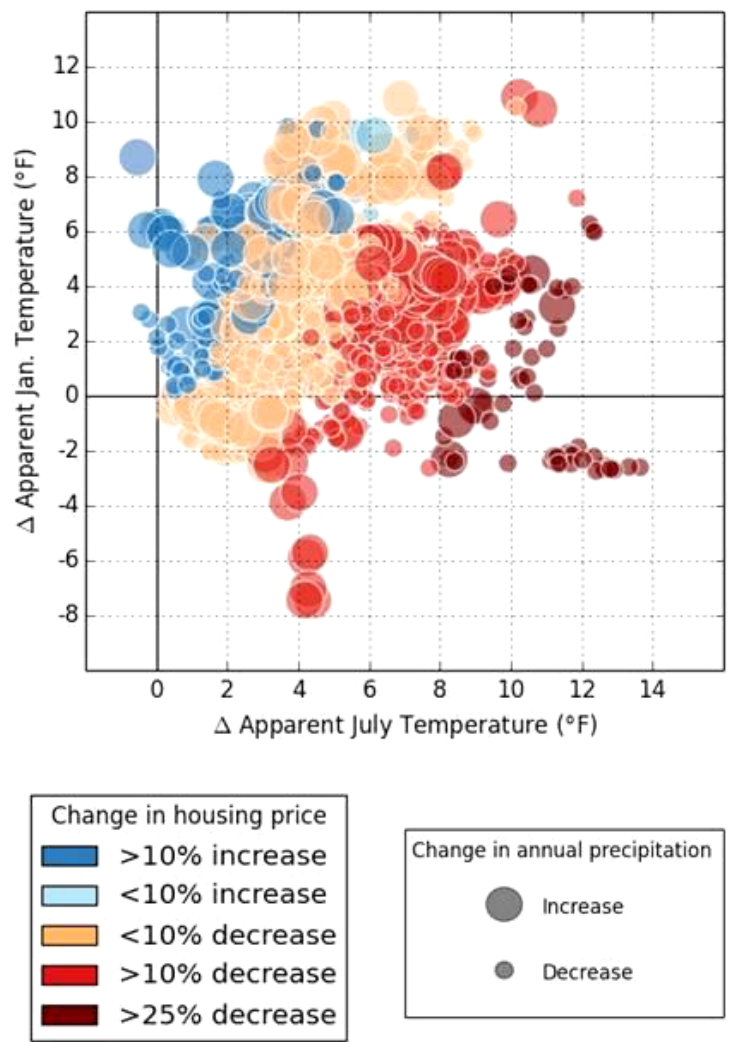

Figure 3. Scatterplot of change in county-level housing price (primary model) in relation to the change in (apparent) temperatures for January ( $x$-axis) and July ( $y$-axis). Colors depict changes in price; circle size denotes increase (large circle) or decrease (small circle) in precipitation.

Seasonal differences in temperature change help to explain why some states gain and others lose - under different climate scenarios. Figure 3 displays the effects of temperature on housing price, for all counties and climate scenarios, and the primary model specification. While summer temperatures are clearly key to the effect of climate on housing prices, the higher the ratio of change in January temperature to change in July apparent temperature, the more likely that climate will produce an amenity value. Overall, counties with a positive amenity value also experience a greater increase in January than July temperatures. Not all counties with a high ratio, however, show an amenity value; where precipitation increases, the disamenity value of an increase in precipitation sometimes outweighs the amenity value of higher January temperatures (Fig. 3).

Although Fig. 2 emphasizes the uncertainty in simulations of future climate, this uncertainty is valuable for understanding the climate-related factors that might influence changes in housing prices. The uncertainty among climate scenarios (i.e., diversity across the model simulations) allows us to build a more robust picture of the sensitivity of housing prices to climate change. We can use the scenarios to span the 
parameter space of climate attributes more completely, thereby building the strong functional relationship represented in Fig. 3.

In addition, the choice of climate model combinations facilitates qualitatively tracing some of the uncertainty in the spatial pattern of housing price shifts back to the GCM and RCM. For example, the January temperature change maps (see Fig. A.2(a) in the online Appendix) are most similar for CS1 and CS4, since they share the same GCM, and large-scale meteorology tends to dominate wintertime temperatures. By contrast, for July apparent temperature change (Fig. A.2(b) in the online Appendix), the scenario that looks most like CS1 is CS2, with which it shares an RCM. In this case, summer temperatures and humidities are likely a function of smaller-scale dynamical and thermodynamical processes controlled by RCM physics. Therefore, the fact that housing price maps (Fig. 2) are most similar for CS1 and CS2 suggests that simulated changes in July apparent temperatures contribute more to the spatial pattern of housing price changes than simulated January temperatures. This in turn suggests that uncertainties rooted in the RCM might be more important than uncertainties associated with the choice and parameterizations of the GCM.

\section{Discussion}

This study explores the relationship between climate variables and housing prices to understand the implications of different climate futures for the amenity value of climate. It is one among a relatively few recent studies that uses household-level data covering large and small cities for both observed climate variables and model-based scenarios of future climate.

Our results support earlier findings on the role of climate in the housing market that show higher average temperatures and warmer winters to be an amenity and warmer more humid summers a disamenity (Maddison and Bigano, 2003; Rehdanz and Maddison, 2009). Results suggest a significant and consistent relationship between housing price and temperature, a relationship that is robust across models. The relationship between housing price and precipitation or humidity is also significant; however, only annual variables performed well. The best performing model includes January and July temperatures (humidity-adjusted), quadratic terms for temperature variables to capture effects of temperature extremes, annual precipitation, annual relative humidity, a variable representing the occurrence of hurricanes, interaction dummy variables to capture differences between large and small cities, and house- and location-specific variables.

Results of the hedonic model combined with the four climate scenarios suggest that climatic changes are associated with an overall loss in housing value nationally, but with large variations from state to state and variations among counties within a state. Across the climate scenarios, the disamenity effects are generally highest in counties east of the 100th meridian, displaying particularly consistent effects in CS1 and CS2, which use the same RCM for downscaling. In two scenarios - CS3 and 
CS4 - amenity effects are strong in some counties in the colder Northeast and Midwest, and in currently drier counties in California and Arizona. A key factor in state-by-state and scenario-by-scenario variation is the ratio of change in January temperature to change in July apparent temperature. The higher this ratio, the more likely that climate will produce an amenity value, with an increase or decrease in annual average precipitation exerting a second-order influence. These results are similar to those of Sinha and Cropper (2013), who find an average welfare loss for US households under climate change, but note that some cities in the Midwest and Northeast benefit.

In the United States, Kahn (2009) evaluated climate amenity values using average county home prices for 53 large metropolitan areas and found that projected changes in January and July temperatures and rainfall negatively affect housing prices. For some cities estimated declines in housing prices exceeded 50\%. Albouy et al. (2013) examined households' willingness-to-pay to avoid heat and cold using cross-sectional variation in wages, housing costs, and climate. They found that households are willing to pay more at the margin to avoid heat than cold, suggesting that most US residents will be worse off as temperatures increase. Sinha and Cropper (2013) also found future summer temperatures to be a disamenity, especially in the south and southeast where these changes are larger than in the northeast; similar to our results, winter warming had a positive value in the northeast (Sinha and Cropper, 2013).

Other studies examined the relationship between future climate and the labor market, rather than housing prices. Nordhaus (1996) examined the relationship between hourly earnings and both annual and seasonal temperatures and precipitation. He found that climate might represent a disamenity ( $0.35 \%$ of aggregate US wages, or $\$ 12$ billion per year at 1995 levels of income and prices). Results were sensitive to assumptions about model specification, leading to a conclusion that the estimated relationship between climate change and amenity values is fragile for labor markets. A subsequent study by Mendelsohn (2001) found that less than $2^{\circ} \mathrm{C}$ warming would lead to annual net benefits in the United States of between $\$ 1$ billion and $\$ 75$ billion, while more severe warming could result in losses. Our results provide additional details in terms of which US regions may realize benefits or losses and under what seasonal circumstances. These nuances are important for developing potential adaptation strategies that may be able to counteract some of the negative effects.

Internationally, studies have examined the value of climate amenities in Great Britain, Brazil, Italy, and Germany (Maddison and Bigano, 2003; Rehdanz, 2006; Timmins, 2007; Rehdanz and Maddison, 2009). These studies suggest that future climate change could reduce amenity values for most households. However, similar to our results (and others conducted for the US), the study in Great Britain found that some locations might benefit from climate change, including places with little or average rainfall and those with large annual temperatures ranges (Rehdanz, 2006).

The amenity value estimated in this study is a proxy for less tangible aspects of climate not easily measured or valued using other market data, such as comfort levels 
and changes in behavioral patterns that depend on weather and climate. An important caveat is that individuals making housing decisions need to be aware of the effects and consider them in decision-making. Amenity value also may capture preferences over changes that can be measured and potentially valued using economic techniques. For example, preferences about climate could result from effects on human health or heating and cooling costs. The climate change impacts and cost of adaptation literature has begun to address these effects (Hadley et al., 2006; Climate Change Science Program, 2007; Deschênes and Greenstone, 2007; Mansur et al., 2008). Where estimated economic values exist, adding amenity values based on hedonic models might be double counting. Thus, while hedonic amenity value is sometimes viewed as a proxy for the value of climate on quality of life, it may fail to capture some important effects and may overstate or double-count others.

Climate change is expected to push the range of plausible experience, in terms of frequency and intensity of extreme events and impacts on aspects of quality-of-life, beyond what has been experienced to date. Like most economic models of human behavior and systems, applications of the hedonic model are best suited to marginal analysis and situations in which simulated results do not extend beyond the range of historical data (Sussman et al., 2011). Further, long-term preferences regarding climate and climate-related amenities may change. Thus, this analysis should be interpreted as indicative of the pressures produced by climate change on some aspects of quality-oflife, and how housing values might reflect those pressures given today's housing market equilibrium and climate.

Finally, the link between climate and housing values may indicate how and to what extent climate change can influence where people choose to live. Integration of the amenity or disamenity value of climate into demographic and land use change models will be important for analyses that describe climate change-related impacts and vulnerabilities (Bierwagen et al., 2010). For example, if the disamenity of warmer summer temperatures and declines in housing prices in the southeast leads to a smaller projected population than without the amenity/disamenity value, the difference could mitigate potential heat impacts (and associated healthcare costs) on an aging population (Voorhees et al., 2011), among other distributional effects.

Advantages of the hedonic housing model are that it is transparent and easy to interpret; coefficients provide clear indications of the contribution of different variables to housing prices and show the effects of key climate variables on housing prices for different climate scenarios. A more complex approach (e.g., panel estimation techniques, or spatial econometrics to adjust for spatial autocorrelation or spatial dependence, or analysis of wage and housing markets simultaneously) might provide results that differ in magnitude from those obtained here and represent potential future research to improve the robustness of results. While the econometric analysis accounts for a number of potentially important climate-related factors affecting amenity values, it does not account for changes over time in some factors (e.g., hurricanes). Incorporating variables into future housing price simulations to capture these and other factors would 
contribute to a fuller understanding of climate impacts and amenity values. Additional climate scenarios also would test the conclusions of this study and facilitate an understanding of the possible range of behaviors of climate amenities and housing prices. The results of this analysis demonstrate the relevance for climate risk assessments of understanding seasonal patterns of future temperature change. This reinforces the need to understand seasonal differences (and intra-seasonal variations) in climate change coming from impact studies in other socioeconomic sectors, such as agriculture, expenditures on energy for heating and cooling, and the value of recreational services, and thus provides a powerful charge to the climate research community.

\section{Acknowledgments}

We wish to thank the North American Regional Climate Change Assessment Program (NARCCAP) for providing data. The National Science Foundation, the US Department of Energy, the National Oceanic and Atmospheric Administration, and the US Environmental Protection Agency Office of Research and Development (EPA/ORD) fund NARCCAP. Comments from J. Gamble, D. Guignet, M. Heberling, E. Kopits, B. Snyder, and P. Walsh improved this manuscript. The EPA/ORD provided financial support for analyses through contracts GS-10F-0124J, Task Order 1101 and EP09C00208, to ICF International. Thanks are also due to A. Little, K. Read, and K. Maher of ICF International for research assistance, and to Megan Holcomb of the US EPA for assistance in generating the maps. The views expressed in this article are those of the authors and do not necessarily reflect the views or policies of the US Environmental Protection Agency.

\section{Supporting Information}

Appendix on Estimates of Changes in County-Level Housing Prices in the United States Under Scenarios of Future Climate Change is available at http://www. worldscinet.com/cce/cce.html.

\section{References}

Albouy, D, W Graf, R Kellogg and H Wolff (2013). Climate Amenities, Climate Change, and American Quality of Life. Working Paper 18925, National Bureau of Economic Research, Cambridge, MA. Available at http://www.nber.org/papers/w18925. Accessed on 1 May 2014 Bierwagen, B, D Theobald, C Pyke, A Choate, P Groth, J Thomas and P Morefield (2010). National housing and impervious surface scenarios for integrated climate impact assessments. In Proceedings of the National Academy of Sciences, 107, 20887-20892.

Clark, D and J Cosgrove (1990). Hedonic prices, identification, and the demand for public safety. Journal of Regional Science, 30, 105-121.

Clark, D and J Cosgrove (1991). Amenities versus labor market opportunities: Choosing the optimal distance to move. Journal of Regional Science, 31, 311-328.

Climate Change Science Program (2007). Effects of climate change on energy production and use in the United States. Washington, DC. 
Cropper, M (1981). The value of urban amenities. Journal of Regional Science, 21, 359-374.

Cropper, M and A Arriaga-Salinas (1980). Inter-city wage differentials and the value of air quality. Journal of Environmental Economics and Management, 16, 106-120.

Deschênes, O and M Greenstone (2007). Climate change, mortality and adaptation: Evidence from annual fluctuations in weather in the US. Center for the Study of Energy Markets, University of California Energy Institute, Berkeley, CA.

Freeman, A (1999). The Measurement of Environmental and Resource Values: Theory and Methods. RFF Press.

Gleckler, P, K Taylor and C Doutriaux (2008). Performance metrics for climate models. Journal of Geophysical Research, 113, D06104.

Gyourko, J and J Tracy (1991). The structure of local public finance and the quality of life. Journal of Political Economy, 99, 774-806.

Hadley, S, D Erickson, J Hernandez, C Broniak and T Blasing (2006). Responses of energy use to climate change: A climate modeling study. Geophysical Research Letters, 33, L17703.

Harrison, D and D Rubinfeld (1978). Hedonic housing prices and demand for clean air. Journal of Environmental Economics and Management, 5, 81-102.

Higgins, R, J Janowiak and Y Yao (1996). A gridded hourly precipitation data base for the United States (1963-1993).

Hoch, I and J Drake (1974). Wages, climate, and the quality of life. Journal of Environmental Economics and Management, 1, 268-295. NCEP/Climate Prediction Center Atlas 1, National Centers for Environmental Prediction, $46 \mathrm{pp}$.

IPCC (2007). Climate change 2007: The physical science basis. Contribution of Working Group I to the Fourth Assessment Report of the IPCC. Cambridge, UK and New York, NY.

Kahn, M (2009). Urban growth and climate change. Annual Review of Resource Economics, 1, 333-349.

Kalnay, E, M Kanamitsu, R Kistler, W Collins, D Deaven, L Gandin, M Iredell, S Saha, G White, J Woollen, Y Zhu, M Chellia, W Ebisuzaki, W Higgins, J Janowiak, K Mo, C Ropelewski, J Wang, A Leetmaa, RE Reynolds, R Jenne and D Joseph (1996). The NCEP/ NCAR 40-Year Reanalysis Project. Bulletin of the American Meteorological Society, 77, 437-471.

Karl, T, JM Melillo and T Peterson (eds.) (2009). Global Climate Change Impacts in the United States. Cambridge: Cambridge University Press.

Koirala, BS and AK Bohara (2014). Valuing US climate amenities for Americans using an hedonic pricing framework. Journal of Environmental Planning and Management, 57, 829847.

Maddison, D and A Bigano (2003). The amenity value of the Italian climate. Journal of Environmental Economics and Management, 45, 319-332.

Mansur, E, R Mendelsohn and W Morrison (2008). Climate change adaptation: A study of fuel choice and consumption in the US energy sector. Journal of Environmental Economics and Management, 55, 175-193.

Mcgranahan, D (1999). Natural Amenities Drive Rural Population Change. Food and Rural Economics Division, U.S. Department of Agriculture, Agricultural Economic Report No. 781.

Mearns, L, W Gutowski, R Jones, L-Y Leung, S Mcginnis, A Nunes and Y Qian (2009). A regional climate change assessment program for North America. EOS, 90, 311-312.

Mearns, LO et al. (2007) (updated 2011). The North American regional climate change assessment program dataset, National Center for Atmospheric Research Earth System Grid data portal, Boulder, CO. Data downloaded 2012-02-09. 
Melillo, JM, TC Richmond and GW Yohe (eds.) (2014). Climate Change Impacts in the United States: The Third National Climate Assessment. U.S. Global Change Research Program, Washington DC.

Mendelsohn, R (2001). A hedonic study of the non-market impacts of global warming in the US. In The Amenity Value of the Global Climate, D Maddison (ed.). London: Earthscan Publications Ltd.

Nordhaus, W (1996). Climate amenities and global warming. In Climate Change: Integrating Science, Economics, and Policy, N Nakićenović, W Nordhaus, R Richels and F Toth (eds.). Laxenburg, Austria: IIASA.

Rehdanz, K (2006). Hedonic pricing of climate change impact to households in Great Britain. Climatic Change, 74, 413-434.

Rehdanz, K and D Maddison (2009). The amenity value of climate to German households. Oxford Economic Papers, 61, 150-167.

Roback, J (1982). Wages, rents and the quality of life. Journal of Political Economy, 90, 1257 1278.

Rosen, S (1979). Wage-based indexes of urban quality of life. In Current Issues in Urban Economics, P Mieszkowski and M Straszheim (eds.), Baltimore: Johns Hopkins University.

Sinha, P and ML Cropper (2013). The Value of Climate Amenities: Evidence from US Migration Decisions. Working Paper 18756, National Bureau of Economic Research, Cambridge, MA. Available at http://www.nber.org/papers/w18756. Accessed on 1 May 2014.

Sussman F, L Clarke, A Grambsch, R Vallario, L Langner, S O’brien, K Jacobs and N Krishnan (2011). Valuation techniques and metrics for climate change impacts, adaptation, and mitigation options: Methodological perspectives for the National Climate Assessment. U.S. Global Change Research Program, Washington, DC, 55 pp.

Sussman F, M Cropper, H Galbraith, D Godschalk, J Loomis, G Luber, M Mcgeehin, J Neumann, W Shaw, A Vedlitz and S Zahran (2008). Effects of global change on human welfare. In Analyses of the Effects of Global Change on Human Health and Welfare and Human Systems. A Report by the US Climate Change Science Program and the Subcommittee on Global Change Research, J Gamble (ed.). US Environmental Protection Agency, Washington DC.

Timmins, C (2007). If you cannot take the heat, get out of the Cerrado. Recovering the equilibrium amenity cost of nonmarginal climate change in Brazil. Journal of Regional Science, 47, 1-25.

Voorhees, AS, N Fann, C Fulcher, P Dolwick, B Hubbell, B Bierwagen and P Morefield (2011). Climate change-related temperature impacts on warm season heat mortality: A proof-of-concept methodology using BenMAP. Environmental Science and Technology, $45,1450-1457$.

Willet, K and S Sherwood (2012). Exceedance of heat index thresholds for 15 regions under a warming climate using the wet-bulb globe temperature. International Journal of Climatology, 32, 161-177. 